\title{
Hubungan Pendidikan Kesehatan Terhadap Pengetahuan Ibu Hamil Tentang Kolostrum di BPM Dewi Suryanti Tahun 2020
}

\author{
Saddiyah Rangkuti \\ Program Studi Kebidanan, Universitas Haji Sumatera Utara
}

\begin{tabular}{|c|c|}
\hline Info Artikel & A B S T R A K \\
\hline $\begin{array}{l}\text { Kata kunci: } \\
\text { Pendidikan Kesehatan, } \\
\text { Pengetahuan Ibu Hamil, } \\
\text { Kolostrum. }\end{array}$ & $\begin{array}{l}\text { Air Susu Ibu (ASI) adalah makanan bayi yang paling penting terutama pada } \\
\text { bulan- bulan pertama kehidupan. Asi eksklusif atau lebih tepat pemberian Asi } \\
\text { secara Eksklusif adalah bayi hanya diberi ASI saja tanpa tambahan cairan lain } \\
\text { seperti susu formula, jeruk, madu, air, teh, air putih tanpa tambahan makanan } \\
\text { padat seperti pisang, pepaya, bubuk susu, biskuit, bubur nasi, dan tim. } \\
\text { Penelitian ini menggunakan jenis penelitian kuantitatif, dengan desain } \\
\text { crosecsional, Populasi dalam penelitian adalah seluruh ibu hamil Trimester III } \\
\text { di BPM Dewi Suryani sebanyak } 43 \text { ibu hamil, Sample dalam penelitian ini } \\
\text { adalah seluruh ibu hamil Trimester III di BPM Dewi Suryani sebanyak } 43 \text { ibu } \\
\text { hamil mulai dari bulan Juni - Agustus } 2020 \text { yaitu sebanyak } 43 \text { dengan teknik } \\
\text { pengambilan sample yaitu total sampling. Hasil penelitian Ada hubungan yang } \\
\text { signifikan antara pendidikan kesehatan terhadap pengetahuan ibu hamil } \\
\text { tentang kolostrum di BPM Dewi Suyanti Tahun } 2020 \text {, dengan nilai p value = } \\
\text { 0,001 (p<0,05). Hal ini berarti bahwa semakin baik pendidikan kesehatan yang } \\
\text { didapatkan oleh ibu hamil tentang kolostrum, maka pengetahuan yang dimiliki } \\
\text { ibu hamil tentang kolostrum akan semakin baik. Kesimpulan Ada hubungan } \\
\text { yang signifikan antara pendidikan kesehatan terhadap pengetahuan ibu hamil } \\
\text { tentang kolostrum di BPM Dewi Suyanti Tahun 2020, saran bagi tempat } \\
\text { penelitian, khususnya dokter, bidan diharapkan meningkatkan penyuluhan } \\
\text { tentang pengetahuan dan perilaku pemberian kolostrum dengan bahasa dan } \\
\text { teknik penyampaian yang mudah diterima, sehingga diharapkan dapat } \\
\text { merubah persepsi/anggapan dan kebiasaan yang buruk terhadap kolostrum. }\end{array}$ \\
\hline
\end{tabular}

\section{Koresponden Penulis:}

Saddiyah Rangkuti,

Program Studi Kebidanan, Universitas Haji Sumatera Utara,

Jl. Rumah Sakit H., Medan Estate, Kec. Percut Sei Tuan, Kabupaten Deli Serdang, Sumatera Utara 20371.

Email: saddiyahrangkuti76@gmail.com

\section{PENDAHULUAN}

Air Susu Ibu (ASI) adalah makanan bayi yang paling penting terutama pada bulan- bulan pertama kehidupan. Asi eksklusif atau lebih tepat pemberian Asi secara Eksklusif adalah bayi hanya diberi ASI saja tanpa tambahan cairan lain seperti susu formula, jeruk, madu, air, teh, air putih tanpa tambahan makanan padat seperti pisang, pepaya, bubuk susu, biskuit, bubur nasi, dan tim (Roesli.U, 2017).

Air Susu Ibu (ASI) sangat ideal untuk bayi yang masih tergantung pada air susu untuk mempertahankan kehidupannya. Pemberian ASI akan berjalan dengan lancar bila bayi diberikan ASI sesering mungkin dan ibu mau menyusuinya serta mempunyai kepercayaan diri bahwa ibu mampu melakukan hal tersebut (Depkes RI, 2016).

World Health Organization (WHO) mengeluarkan standar pertumbuhan anak yang kemudian diterapkan di seluruh belahan dunia. Isinya adalah menekankan pentingnya pemberian ASI saja kepada bayi sejak lahir sampai usia 6 bulan, ini berarti bahwa bayi hanya menerima ASI dari ibu atau dari pengasuh yang diminta ibu untuk memberikan ASI, tanpa penambahan cairan atau makanan padat lain, kecuali sirup yang berisi vitamin, suplemen, mineral ataupun obat. Setelah itu 
barulah bayi diberikan Makanan Pendamping ASI (MP-ASI) sambil tetap disusui hingga usianya mencapai 2 tahun. Cakupan ASI Eksklusif di negara ASEAN seperti India sudah mencapai 46\%, di Philippines 34\%, di Vietnam 27\% dan di Myanmar 24\% ( Harwono.A, 2018)

Menurut WHO (World Health Organization), bahwa setiap tahun terdapat 1-1,5 juga bayi di dunia yang meninggal karena tidak diberi ASI Eksklusif (Roesli 2016). Akhir-akhir ini, sebuah analisis menerangkan bahwa memberikan ASI selama 6 bulan dapat menyelamatkan 1,3 juta jiwa di seluruh dunia, termasuk $22 \%$ nyawa yang melayang setelah kelahiran. Sementara itu, menurut UNICEF (United Nations Childred's Fund), ASI eksklusif dapat menekan angka kematian bayi di Indonesia. UNICEF menyatakan bahwa 30.000 kematian bayi di Indonesia dan 10 juta kematian anak balita di dunia setiap tahun bisa dicegah melalui pemberian ASI eksklusif selama enam bulan sejak sejam pertama setelah kelahirannya tanpa memberikan makanan dan minuman tambahan kepada bayi (Prasetyono, 2016).

Di Indonesia melalui Keputusan Menteri Kesehatan Nomor 450/SK/Menkes/VIII/2004, Telah menetapkan pemberian ASI eksklusif selama 6 bulan pada ibu di Indonesia. Menurut data survei sosial ekonomi nasional (Susenas) 2010 menunjukkan bahwa baru 33,6\% bayi mendapatkan ASI di indonesia yang disebabkan karena banyak faktor, diantaranya menurut Data Riset Fasilitas Kesehatan Dasar 2018 mengungkapkan bahwa baru sekitar 40\% Rumah Sakit yang melaksanakan Rumah Saktit sayang ibu dan bayi sebagai 10 langkah keberhasilan menyusui. Hal lain yang mendukung pernyataan di atas yaitu pada 2016 berdasarkan hasil rapid assesment menemukan banyak Rumah Sakit Pemerintah dan Swasta menerima sponsor dan hadiah berupa sampel Susu formula, kalender, kartu status anak dan bentuk lainnyan yang melemahkan upaya peningkatan pemberian ASI Eksklusif.

Menururt data pada tahun 2015 yang diambil dari Riset Kesehatan Dasar, persentase bayi yang mendapat ASI ekslusif di Indonesia adalah 15,3\% Kendala yang dihadapi dalam praktek ASI eksklusif adalah kurangnya pengetahuan ibu, kurangnya dukungan dari lingkungan dan praktisi kesehatan, pemberian makanan dan minuman terlalu dini, serta maraknya promosi susu formula untuk bayi (Harwono.A, 2018).

Di Sumatera Utara jumlah bayi usia 0-6 yang mendapat ASI Eksklusif pada tahun 2018 sebanyak 46.244 bayi dan yang mendapat ASI Eksklusif sebesar 16.164 bayi. Cakupan pemberian ASI Eksklusif tahun 2018 adalah sebesar 19,2 \%. Rendahnya cakupan ASI eksklusif disebabkan ketidaktahuan ibu akan gunanya ASI, gencarnya iklan susu formula, kurang trampilnya dan kurang pedulinya petugas kesehatan pada kebutuhan ibu dan bayi tentang manajemen laktasi (www.sulutprov.go.id/diskes1/gizi.html, 2018).

Kolostrum adalah cairan pertama yang disekresi oleh kelenjar payudara (Soetjiningsih, 2017). Kandungan tertinggi dalam kolostrum adalah antibody yang siap melindungi bayi ketika kondisi bayi masih sangat lemah. Kandungan protein dalam kolostrum lebih tinggi dibandingkan dengan kandungan protein dalam susu matur (Purwanti, 2017).

Pemberian kolostrum dapat dimulai sejak satu jam pertama bayi dilahirkan dengan melakukan praktik inisiasi menyusu dini (IMD). Pendekatan IMD yang sekarang dianjurkan adalah dengan metode breast crawl (merangkak mencari payudara) dimana setelah bayi lahir segera diletakkan di perut ibu dan dibiarkan merangkak untuk mencari sendiri puting ibunya dan akhirnya menghisapnya tanpa bantuan (Februhartanty J, 2016)

Beberapa pendapat yang menghambat ibu nifas memberikan kolostrum dengan segera, diantaranya takut bayi kedinginan, setelah melahirkan ibu terlalu lelah untuk menyusui bayinya, kolostrum tidak keluar atau jumlah kolostrum tidak memadai, serta kolostrum tidak baik dan berbahaya bagi bayi. Hal di atas tidak akan terjadi jika seorang ibu nifas mempunyai pengetahuan yang bagus serta mendapat dukungan dari keluarga(Roesli, 2018).

Menurut Khasanah, 2016 mengatakan banyak Ibu-ibu yang beranggapan bahwa kolostrum tidak layak diberikan pada bayi padahal di dalam kolostrum mengandung $15 \%$ protein yang terdiri dari laktalbumin, laktaglobulin, dan kasein yang semuanya sangat berguna untuk membantu pencernaan bayi, sehingga kotoran yang dikeluarkan tidak terlalu keras dan tidak terlalu lembek. Selain itu juga kolostrum mengandung berbagai zat antibody yang memberikan kekebalan terhadap berbagai penyakit infeksi seperti gastroeoteritis, batuk rejan, tetanus, dan kolostrum juga memiliki

JURKESMAS : Jurnal Kesehatan Masyarakat, Vol. 1, No. 1, Juli 2021: 7 - 13 
efek laksatif yang akan mambantu bayi mengeluarkan tinja dari sistem percernaan sehingga efeknya juga akan membantu mengeluarkan bilirubin dari darah dan melindungi bayi dari kuning (Aundice).

Berdasarkan data Rumah Sakit Panembahan Senopati Bantul Yogyakarta tahun 2014 jumlah pasien melahirkan sebanyak 1.159 orang, dan rata-rata ibu nifas tiap bulan di Ruang Alamanda III Rumah Sakit Panembahan Senopati Bantul sebanyak 114 orang. Hasil survey awal yang dilakukan peneliti kepada 11 orang pasien ibu nifas di Rumah Sakit Panembahan Senopati Bantul, didapatkan data bahwa 6 orang ibu mengetahui tentang kolostrum serta memberikan kepada bayinya sedangkan 5 orang ibu tidak mengetahui tentang kolostrum dan tidak memberikan kepada bayinya. Menurut ibu hal ini dilakukan karena tidak mengetahui manfaat kolostrum bagi bayi.

Kebijakan pemerintah terhadap masalah ini adalah dengan memberikan program pemberian ASI secara eksklusif, penddikan kesehatan pemberian kolostrum 1 jam setelah melahirkan. Dalam pelaksanaanya, ibu-ibu nifas diberikan pendidikan kesehatan tentang pemberian kolestrum oleh tenaga kesehatan dari puskesmas terdekat (Proverawati, 2018).

Pendidikan kesehatan adalah suatu penerapan konsep pendidikan kesehatan. Pendidikan kesehatan dapat didefinisikan sebagai usahaa atau kegiatan untuk membantu individu, kelompok atau masyarakat dalam meningkatkan kemampuan (perilakunya), untuk mencapai kesehatan secara optimal (Aryastuti, 2017). Pendidikan kesehatan merupakan tindakan penting, yang perlu dilakukan dalam upaya meningkatkan pengetahuan ibu-ibu mengenai pemberian kolostrum (Nasution, 2014)

Azwar dalam Machfoedz (2018), penyuluhan kesehatan adalah kegiatam pendidikan pendidikan kesehatan, yang dilakukan dengan menyebarkan pesan, menanamkan keyakinan, sehingga masyarakan tidak saja sadar, tahu dan mengerti, tetapu juga mau dan bisa melakuakan suatu anjuran yang ada hubunganya dengan kesehatan. Dengan memebrikan penyuluhan, diharapkan masyarakat bisa lebih siapa dalam pemberian ASI eksklusif sehingga dapat menurunkan kekhawatiran mereka dan meningkatkan perilaku hidup sehat masyarakat.

Berkenaan dengan pentingnya peran promosi kesehatan dalam pelayanan kesehatan, telah ditetapkan kebijakan Nasional Promosi Kesehatan sesuai dengan Surat keputusan menteri kesehatan Nomor 1193/Menkes/SK/X/2016. Kebijakan dimaksud juga didukung dengan Surat keputusan Menteri Kesehatan Nomor 1114/Menkes/SK/VII/2005 tentang Pedoman Pelaksanaan Promosi Kesehatan di Daerah.

Untuk melaksanakan upaya kesehatan wajib tersebut di puskesmas dan klinik bersalin diperlukan Penyuluh Kesehatan mengenai manfaat pemberian kolostrum untuk mengelola promosi kesehatan di puskesmas dan klinik bersalin secara professional dan mampu untuk mengelola serta menyelenggarakan pelayanan yang bersifat promotif dan preventif melihat pengetahuan ibu tentang pengetahuan tentang ibu nifas.

Beberapa penelitian melaporkan faktor-faktor yang mempengaruhi kejadian awal pemberian kolostrum yaitu pengetahuan ibu yang sangat minim, dan faktor pemberi informasi yaitu petugas kesehatan yang tidak mau memberi informasi mengenai proses laktasi dan manfaatnya bagi ibu dan bayi.

Berdasarkan survey awal yang dilakukan pada tanggal 28 Maret 2020 melalui wawancara secara langsung kepada ibu nifas dengan melalui wawancara yang direkam mengunakan tape recorder, ibu mengatakan bahwa tidak pendampatkan pendidikan kesehatan mengenai pemberian kolostrum hal itu disebabkan oleh pengetahuan ibu yang kurang terhadap memberian kolostrum.

\section{METODE PENELITIAN}

Penelitian ini dilakukan di BPM Dewi Suyanti. Wilayah Dewi Suyanti. BPM Dewi Suyanti merupakan bentuk pelayanan kesehatan dibidang kesehatan dasar sesuai dengan kewenangan dan kemampuan bidan. BPM Dewi Suyanti memberikan pelayanan selama 24 jam untuk masyarakat, dan memiliki tempat dan ruangan praktek yang memenuhi persyaratan kesehatan, mempunyai tempat tidur untuk persalinan dan memiliki 5 tempat tidur, memiliki peralatan yang sesuai dengan ketentuan dan menyediakan obat-obatan sesuai dengan ketentauan yang berlaku.

\section{HASIL DAN PEMBAHASAN}

\subsection{Hasil}

\section{Analisa Univariat}

Hubungan Pendidikan Kesehatan Terhadap Pengetahuan Ibu Hamil ... (Saddiyah Rangkuti) 
Berdasarkan hasil penelitian di BPM Dewi Suyanti Tahun 2020 diketahui data karakteristik responden berdasarkan umur, pendidikan, dan pekerjaan yang diperoleh dari 43 responden. Hasil data karakteristik responden disajikan dalam bentuk tabel dibawah ini:

Tabel 4.1. Data Karakteristik Responden di BPM Dewi Suyanti Tahun 2020

\begin{tabular}{|c|c|c|c|}
\hline No & Data Demografi & Frekuensi & Presentase (\%) \\
\hline \multirow[t]{6}{*}{1} & Umur & & \\
\hline & $\leq 25$ tahun & 3 & 7,0 \\
\hline & 26-30 tahun & 16 & 37,2 \\
\hline & $31-35$ tahun & 14 & 32,6 \\
\hline & $>35$ tahun & 10 & 23,3 \\
\hline & Jumlah & 43 & 100 \\
\hline \multirow[t]{5}{*}{2} & Pendidikan & & \\
\hline & SMP & 18 & 41,9 \\
\hline & SMA & 21 & 48,8 \\
\hline & Perguruan Tinggi & 4 & 9,3 \\
\hline & Jumlah & 43 & 100 \\
\hline \multirow[t]{5}{*}{3} & Pekerjaan & & \\
\hline & IRT & 24 & 55,8 \\
\hline & Wiraswasta & 16 & 37,2 \\
\hline & PNS & 3 & 7,0 \\
\hline & Jumlah & 43 & 100 \\
\hline
\end{tabular}

Dari tabel 1 di atas karakteristik responden berdasarkan umur mayoritas 26-30 tahun sebanyak 16 orang $(37,2 \%)$ dengan tingkat pendidikan mayoritas SMA sebanyak 21 orang $(48,8 \%)$ dan berdasarkan pekerjaan mayoritas sebagai IRT sebanyak 24 orang $(55,8 \%)$.

Distribusi frekuensi data pendidikan kesehatan kolostrum di BPM Dewi Suyanti Tahun 2020 dapat dilihat pada tabel 2 di bawah berikut:

Tabel 2. Distribusi Frekuensi Data pendidikan kesehatan kolostrum di BPM Dewi Suyanti Tahun 2020

\begin{tabular}{cccc}
\hline No & Pendidikan Kesehatan Kolostrum & Frekuensi & Persentase (\%) \\
\hline 1 & Baik & 8 & 18,6 \\
2 & Cukup & 20 & 46,5 \\
3 & Kurang & 15 & 34,9 \\
\hline & Jumlah & 43 & 100 \\
\hline
\end{tabular}

Berdasarkan tabel 2 di atas diketahui bahwa pendidikan kesehatan kolostrum di BPM Dewi Suyanti Tahun 2020 mayoritas dalam kategori cukup sebanyak 20 orang (46,5\%).

Distribusi frekuensi data pengetahuan ibu hamil tentang kolostrum di BPM Dewi Suyanti Tahun 2020 dapat dilihat pada tabel 3 di bawah berikut:

Tabel 3. Distribusi Frekuensi Data Pengetahuan Ibu Hamil Tentang Kolostrum di BPM Dewi Suyanti Tahun 2020

\begin{tabular}{cccc}
\hline No & Pengetahuan Ibu Hamil & Frekuensi & Persentase (\%) \\
\hline 1 & Baik & 10 & 23,3 \\
2 & Cukup & 22 & 51,2 \\
3 & Kurang & 11 & 25,6 \\
\hline & Jumlah & 43 & 100 \\
\hline
\end{tabular}

Berdasarkan tabel 3 di atas diketahui bahwa pengetahuan ibu hamil tentang kolostrum di BPM Dewi Suyanti Tahun 2020 mayoritas dalam kategori cukup sebanyak 22 orang (51,2\%).

\section{Analisa Bivariat}

Data analisis hubungan pendidikan kesehatan terhadap pengetahuan ibu hamil tentang kolostrum di BPM Dewi Suyanti Tahun 2020 dapat dilihat pada tabel 4 berikut

Tabel 4. Tabulasi Silang Hubungan pendidikan kesehatan terhadap pengetahuan ibu hamil tentang kolostrum di BPM Dewi Suyanti Tahun 2020

\begin{tabular}{|c|c|c|c|c|c|c|c|c|c|}
\hline \multirow{3}{*}{$\begin{array}{c}\text { Pendidikan } \\
\text { Kesehatan }\end{array}$} & \multicolumn{6}{|c|}{ Pengetahuan Ibu tentang Kolostrum } & \multirow{2}{*}{\multicolumn{2}{|c|}{ Total }} & \multirow{3}{*}{$p$-value } \\
\hline & \multirow{2}{*}{\multicolumn{2}{|c|}{ Baik }} & \multicolumn{2}{|c|}{ Cukup } & \multirow{2}{*}{\multicolumn{2}{|c|}{$\begin{array}{c}\text { Kurang } \\
f \quad\end{array}$}} & & & \\
\hline & & & $\mathrm{f}$ & $\%$ & & & $\mathrm{f}$ & $\%$ & \\
\hline
\end{tabular}




\begin{tabular}{cccccccccc}
\hline Baik & 4 & 9,3 & 3 & 7,0 & 1 & 2,3 & 8 & 18,6 \\
Cukup & 6 & 14,0 & 13 & 30,2 & 1 & 2,3 & 20 & 46,5 & \\
Kurang & 0 & 0,0 & 6 & 14,0 & 9 & 20,9 & 15 & 34,9 & 0,001 \\
\cline { 1 - 7 } Total & 10 & 23,3 & 22 & 51,2 & 11 & 25,6 & 24 & 100,0 & \\
\hline
\end{tabular}

Berdasarkan data pada tabel 4 di atas dapat diketahui bahwa 8 ibu hamil yang mendapat pendidikan kesehatan yang baik mayoritas memiliki pengetahuan yang baik tentang kolostrum yaitu 4 orang $(9,3 \%)$. Selanjutnya dari 20 ibu hamil yang mendapat pendidikan kesehatan yang cukup mayoritas memiliki pengetahuan yang cukup tentang kolostrum yaitu 13 orang $(30,2 \%)$. Sedangkan dari 15 ibu hamil yang kurang mendapat pendidikan kesehatan mayoritas memiliki pengetahuan kurang tentang kolostrum.

Selanjutnya berdasarkan pengolahan data pada tabel 4 di atas diketahui bahwa nilai p-value signifikan yaitu $0,001 \mathrm{p}$-value $<0,05$ maka Ho ditolak dan Ha diterima sehingga pada penelitian ini terdapat hubungan yang signifikan pendidikan kesehatan terhadap pengetahuan ibu hamil tentang kolostrum di BPM Dewi Suyanti Tahun 2020. Hal ini menunjukkan bahwa semakin baik pendidikan kesehatan yang didapatkan oleh ibu hamil tentang kolostrum, maka pengetahuan yang dimiliki ibu hamil tentang kolostrum akan semakin baik.

\subsection{Pembahasan}

Pendidikan kesehatan tentang kolostrum di BPM Dewi Suyanti Tahun 2020

Hasil penelitian diketahui bahwa pendidikan kesehatan tentang kolostrum di BPM Dewi Suyanti Tahun 2020 mayoritas dalam kategori cukup sebanyak 20 orang (46,5\%). Pendidikan kesehatan tentang kolostrum yang diperoleh ibu hamil masih tergolong cukup disebabkan oleh minimnya program penyuluhan yang dilakukan oleh pihak puskesmas maupun dari dinas kesehatan setempat sehingga ibu hamil tidak pernah mengikuti pendidikan kesehatan tentang kolostrum. Selain itu faktor pekerjaan dan kesibukan juga menjadi halangan untuk ibu mengikuti penyuluhan tentang kolostrum tersebut.

Dari hasil penelitian Kustini (2018) menyebutkan bahwa petugas kesehatan mempunyai peranan dalam memberikan informasi tentang manfaat kolostrum, Paritas, Seorang ibu dengan bayi pertama mungkin akan mengalami masalah ketika menyusui yang sebetulnya hanya karena tidak tahu cara menyusui yang sebenarnya, serta faktor ekonomis: dengan memberikan kolostrum yang langsung kepada bayi setelah lahir, ibu tidak perlu mengeluarkan biaya sehingga akan menghemat pengeluaran.

Selain itu dalam penelitian Sunesti (2018) menyebutkan bahwa responden dengan kategori tingkat pendidikan rendah sedikit memberikan kolostrum sedangkan responden dengan kategori tingkat pendidikan tinggi lebih banyak memberikan kolostrum. Hal ini menunjukkan bahwa semakin tinggi tingkat pendidikan, semakin tinggi perilaku pemberian kolostrum terhadap bayinya. Sebaliknya, semakin rendah tingkat pendidikan responden maka semakin rendah perilaku pemberian kolostrum. Karena dengan semakin tinggi pendidikan berarti semakin luas wawasan responden dalam mendapatkan maupun mencari suatu informasi.

Menurut hasil penelitian, adanya pendidikan kesehatan tentang kolostrum diharapkan akan terjadi perubahan perilaku yaitu dari tidak memberikan ASI eksklusif berubah memberikan ASI eksklusif pada bayinya. Hal tersebut sesuai dengan tujuan pendidikan kesehatan sebagaimana dijelaskan oleh Suminjatun (2012) yaitu tujuan pendidikan kesehatan adalah tercapainya perubahan perilaku individu, keluarga dan masyarakat dalam membina dan memelihara perilaku hidup sehat dan lingkungan sehat, serta berperan aktif dalam upaya mewujudkan derajat kesehatan yang optimal. Pengetahuan Ibu Hamil Tentang Kolostrum di BPM Dewi Suyanti Tahun 2020

Berdasarkan hasil penelitian diketahui bahwa pengetahuan ibu hamil tentang kolostrum di BPM Dewi Suyanti Tahun 2020 mayoritas dalam kategori cukup sebanyak 22 orang $(51,2 \%)$. Namun ibu yang memiliki pengetahuan kurang masih sekitar 25,6\%. Masih kurangnya pengetahuan ibu terhadap manfaat pemberian kolostrum menyebabkan kurangnya motivasi ibu untuk memberikan kolostrum. Hal ini dengan penelitian Sukari (2014) yang menyatakan bahwa dengan pendidikan tinggi maka seseorang akan cenderung lebih mudah untuk mendapatkan informasi, baik dari orang lain maupun dari media massa. Sedangkan semakin rendah pendidikan akan mempengaruhi tingkat pengetahuan seseorang (Sukari, Rompas, \& Bataha, 2014). 
Hasil karakteristik responden menunjukkan bahwa sebagian besar responden berpendidikan SMA sebanyak 20 orang $(48,8 \%)$ dan yang berpendidikan rendah (SMP) sebanyak 18 orang $(41,9 \%)$ Pendidikan seseorang berpengaruh pada pengetahuannya, di mana semakin tinggi pendidikan seseorang, makin banyak pula pengetahuan yang dimiliki. Sebaliknya, pendidikan yang rendah / kurang akan menghambat perkembangan sikap seseorang terhadap nilai baru yang di perkenalkan sehingga pengetahuan juga kurang. Hal ini terbukti dari hasil penelitian yaitu bahwa tingkat pengetahuan ibu post partum tentang manfaat kolostrum berpengaruh pada pemberian kolostrum pada bayi baru lahir. Dengan tingkat pengetahuan yang rendah lebih berpotensi tidak memberikan kolostrum di bandingkan dengan tingkat pengetahuan yang lebih tinggi. Pengetahuan atau kognitif merupakan domain yang sangat penting untuk terbentuknya tindakan seseorang (overt behavior). Sebelum orang mengadopsi perilaku baru, di dalam diri seseorang tersebut. (Notoatmodjo, 2013)

Hasil penelitian menunjukkan tingkat pengetahuan responden tentang kolostrum adalah cukup. Hal ini dipengaruhi oleh beberapa Faktor-faktor yang mempengaruhi awal pemberian Kolostrum yaitu petugas kesehatan, psikologi ibu yaitu kepribadian dan pengalaman ibu, sosiobudaya, tata laksana rumah sakit, pendidikan, umur, pekerjaan, kesehatan ibu dan anak, pengetahuan ibu mengenai Manfaat Kolostrum, lingkungan keluarga, peraturan pemasaran pengganti ASI dan jumlah anak (Dwi Hapsari, 2010).

Menurut asumsi peneliti, pengetahuan responden yang masih tergolong cukup tentang kolostrum disebabkan oleh masih kurangnya informasi yang diterima oleh ibu hamil tentang kolostrum yang bersumber dari penyuluhan maupun media massa. Selain itu, keingintahuan ibu tentang kolostrum juga tergolong masih kurang disebabkan oleh tidak pahamnya masyarakat tentang manfaat kolostrum.

Hubungan Pendidikan Kesehatan Terhadap Pengetahuan Ibu Hamil Tentang Kolostrum di BPM Dewi Suyanti Tahun 2020

Berdasarkan data analisis tabulasi silang dapat diketahui bahwa 8 ibu hamil yang mendapat pendidikan kesehatan yang baik mayoritas memiliki pengetahuan yang baik tentang kolostrum yaitu 4 orang $(9,3 \%)$. Selanjutnya dari 20 ibu hamil yang mendapat pendidikan kesehatan yang cukup mayoritas memiliki pengetahuan yang cukup tentang kolostrum yaitu 13 orang $(30,2 \%)$. Sedangkan dari 15 ibu hamil yang kurang mendapat pendidikan kesehatan mayoritas memiliki pengetahuan kurang tentang kolostrum.

Selanjutnya berdasarkan pengolahan data diketahui bahwa nilai p-value signifikan yaitu 0,001 p-value < 0,05 maka Ho ditolak dan Ha diterima sehingga pada penelitian ini terdapat hubungan yang signifikan pendidikan kesehatan terhadap pengetahuan ibu hamil tentang kolostrum di BPM Dewi Suyanti Tahun 2020. Hal ini menunjukkan bahwa semakin baik pendidikan kesehatan yang didapatkan oleh ibu hamil tentang kolostrum, maka pengetahuan yang dimiliki ibu hamil tentang kolostrum akan semakin baik.

Hasil penelitian ini sejalan dengan penelitian Sunesni (2018) bahwa ada hubungan pengetahuan dengan perilaku pemberian kolostrum di Kelurahan Gunung Sarik Wilayah Kerja Puskesmas Belimbing tahun 2018, dengan p value $=0,006(p<0,05)$. Kondisi ini menggambarkan bahwa responden dengan kategori tingkat pengetahuan rendah sedikit memberikan kolostrum sedangkan responden dengan kategori tingkat pengetahuan tinggi lebih banyak memberikan kolostrum. Hal ini menunjukkan bahwa semakin tinggi tingkat pengetahuan responden, semakin tinggi perilaku pemberian kolostrum terhadap bayinya. Sebaliknya, semakin rendah tingkat pengetahuan responden maka semakin rendah perilaku pemberian kolostrum.

Menurut penelitian Kustini (2018) bahwa Pemberian kolostrum merupakan perilaku atau tindakan ibu. Dimana tindakan ibu tersebut dipengaruhi oleh pengetahuan tentang manfaat kolostrum. bahwasanya pengetahuan adalah faktor yang sangat penting untuk terbentuknya perilaku atau tindakan untuk merubah perilaku seseorang yang disengaja. Kemudian muncul respons dalam bentuk sikap terhadap obyek yang telah diketahui dan disadari sepenuhnya, selanjutnya dari respon sikap dibentuk perilaku. Berdasarkan pengalaman dan penelitian ternyata perilaku yang didasari oleh pengetahuan akan lebih bertahan lama dari pada perilaku yang tidak didasari oleh pengetahuan.

Menurut hasil penelitian, jika pendidikan kesehatan yang diterima ibu hamil sudah baik, maka pengetahuan yang dimiliki ibu hamil juga akan semakin baik, karena mereka sudah memahami 
manfaat dari kolostrum itu sendiri. Sebaliknya jika pendidikan kesehatan diterima masih kurang secara otomatis pengetahuan yang ibu miliki tentang kolostrum juga masih kurang.

\section{KESIMPULAN}

Pendidikan kesehatan tentang kolostrum di BPM Dewi Suyanti Tahun 2020 mayoritas dalam kategori cukup sebanyak 46,5\%. Pengetahuan ibu hamil tentang kolostrum di BPM Dewi Suyanti Tahun 2020 mayoritas diberikan oleh bidan sebanyak $51,2 \%$. Ada hubungan yang signifikan antara pendidikan kesehatan terhadap pengetahuan ibu hamil tentang kolostrum di BPM Dewi Suyanti Tahun 2020, dengan nilai $p$ value $=0,001(p<0,05)$. Hal ini berarti bahwa semakin baik pendidikan kesehatan yang didapatkan oleh ibu hamil tentang kolostrum, maka pengetahuan yang dimiliki ibu hamil tentang kolostrum akan semakin baik.

\section{REFERENCES}

Andini. 2016. 14 Keajaiban Kolostrum. Jakarta

Arikunto. 2016. Dasar-dasar Evaluasi Pendidikan. Jakarta : Bumi Aksara 2017. Prosedur Penelitian. Jakarta : Rineka Cipta

Budiarto, Eko. 2017. Metodologi Penelitian Kesehatan : Sebuah Pengantar. Jakarta : Rineka Cipta.

Buharminin.2017.Penelaah Status Pendidikan Nasional.2017.Bandung : Kawan Pustaka

Cahyaning, R (2016), Faktor-Faktor Yang Berhubungan Dengan Pemberian ASI Pertama Kali di Puwarkarta, Jabar. Skripsi FKM-UI. Tidak dipublikasikan

Curtis. 2016. Telaah Air SusuIbu. Edisi II

Dwi Hapsari. 2016. Breastfeeding Colostrum, Surabaya, Pusat Pengembangan Kesehatan. NHRD.

Hurlock. 2017. Psikologi Perkembangan. Jakarta : EGC. http://www.ekologi.litbang.depkes.go.id/abstrak 2016.html, diperoleh tanggal 11 April 2017.

Notoatmodjo. S. 2017. Metodologi Penelitian Kesehatan. Edisi Revisi VI. Jakarta : PT. Rineka Cipta.

PUSDIKNAKES. 2017. Buku 4 Asuhan Kebidanan Post Partum. Jakarta : Pusdiknakes.

PUSDIKNAKES. 2017.Ekologi Kesehatan.Com, Edisi 46/Thn-II/2016

Ragil, M (2017), Hubungan Karakteristik Ibu dan Pengetahuan Tentang ASI Terhadap Praktek Pemberian Kolostrum di Kabupaten Serang Jabar. Skripsi FKM UI

Rini. 2016. Menyelamatkan Bayi Lewat ASI, Jakarta: Rineka Cipta

Roesli. 2016. Mengenal ASI Exklusif. Jakarta : Pustaka Pengembangan Swadaya Nusantara.

Sarwono. 2017. Ilmu Kebidanan. Jakarta : Yayasan Bina Pustaka Sobur, A (2017). Psikologi Umum. Bandung : Pustaka Setia Soetjiningsih. 2017. ASI Petunjuk V Tenaga Kesehatan. Jakarta : EGC. 